\title{
PANEGÍRICO DE NICOLAU NAZO \\ (Oração oficial de seu Centenário comemorado na Faculdade de Direito do Largo de São Francisco)
}

\author{
Rubens Limongi França \\ Professor honorário da Faculdade de Direito da Universidade de São Paulo
}

Como soe acontecer, por entre as curvas acolhedoras destas vetustas arcadas, para as quais convergem as mais refinadas vibrações que as fazem como misto de lar, mosteiro e campanário - voltam os seus claustros e os seus salões a recolherem-se em si mesmo, numa reverente contrição, em homenagem a um dos mais ilustres dos seus filhos, o saudoso Professor Nicolau Nazo, cujo centenário hoje se comemora.

Lar - a Faculdade de Direito do Largo de São Francisco, foi a casa espiritual do mestre, nos dias da adolescência e na primeira juventude, onde privou e cresceu, ora como colega, ora como aluno, em companhia de espíritos de escol, do coturno de Antônio Alcântara Machado, Francisco Patti, Menotti del Picchia e Vicente Ráo, tendo merecido do primeiro, ao lado dos demais, todos inspiradores dos "Gaetaninhos"- os filhos bem-sucedidos de imigrantes italianos, a dedicatória do esplêndido livro Braz, Bexiga de Barra Funda, incomparável crônica da belle époque da já então Paulicéia Desvairada.

Mosteiro - aqui cumpriu o noviciado de sua formação na sacrossanta religião do Direito e da Justiça e sem deixar de participar, de modo um tanto retraído, das tropelias da vida acadêmica, aprendeu a tirar de dentro de si mesmo a múltipla riqueza de sua personalidade privilegiada, na qual o Criador imprimira o dom de todas as virtudes a atributos, em meio aos quais realçam desde logo a bondade, a paciência, a benevolência, moldura e fundo de outras tantas grandezas, como a inteligência arguta, a memória prodigiosa e a tenacidade inquebrantável.

Campanário - foi dos zimbórios espirituais desta Casa que, recémformado, partiu para o exercício de uma tríplice atividade jurídica, a saber, de advogado, de escritor e de professor, sendo absolutamente impossivel discernir em qual dessas perspectivas terá sido mais brilhante e mais completo pois, em todos esses campos, se tornou magistral exemplo.

Não fui eu companheiro ou auxiliar de escritório mas, incidentalmente, no início de minha advocacia, do mestre ouvi muitos conselhos 
úteis, devendo consignar que fui seu aluno no Instituto de Direito Social e seu assistente nestas Arcadas, onde ingressei por sua mão, no que contei ainda com o apoio irrestrito do então Diretor Professor Luís Eulálio de Bueno Vidigal, também de saudosíssima memória.

Tão privilegiada situação possibilitou-me a dádiva de conhecê-lo muito de perto, além do que era recebido em seu lar com o afeto que se dispensa a um verdadeiro filho. E aí devo dizer que não menor era a generosidade de sua incomparável consorte, D. Georgette Nacarato Nazo, companheira, colaboradora e incentivadora de todas as horas, bem assim de suas filhas muito especiais, na graça e no talento, nitidamente peninsulares, a Gettinha e a Nanette.

Como esta relação quase paterno-filial começou pelos inícios de 1946, pude acompanhar a fase mais brilhante de sua carreira, ao longo dos cinco lustros finais de existência larga e profícua.

No Instituto de Direito Social do qual, ao lado de outros homens excepcionais, como Agnaldo Miranda Simões, Ruy Sodré, Cesarino Júnior e João Scantinburgo, foi um dos fundadores tive a graça de lhe ouvir aulas na disciplina de Economia Social.

Coincidindo com as de Economia Política da Faculdade Paulista de Direito, ministradas por meu tio e mestre João Papaterra Limongi, de ambos auferia a infra-estrutura sócio-econômica e humanística de minha formação em Direito Civil.

$\mathrm{Na}$ década de 50, eu já era bacharel e acompanhei de longe a brilhante ascensão universitária do mestre, ao fazer os concursos de Livre-Docência de Direito Internacional Privado nestas Arcadas, de cátedra da mesma matéria na Universidade Católica e de Livre-Docência de Introdução à Ciência do Direito, outra vez no Largo de São Francisco, embates esses nos quais brindou a Ciência Jurídica com obras de grande originalidade, especialmente, neste último ensejo, quando apresentou a tese Principios Gerais de Direito.

A essa altura, não obstante, desde 1952, estar exercendo a função de assistente de João Papaterra Limongi, o qual vim a suceder interinamente, 1961, na cátedra de Economia Política, eu começara a preparar por conta própria as minhas Instituições de Direito Civil, de cujos capítulos iniciais saiu da tese doutoral Do Nome Civil das Pessoas Naturais, defendida em 1959.

O mestre Nicolau Nazo e este seu discípulo, embora estivéssemos também cuidando de outras matérias, amávamos ambos de modo especial o Direito 
Civil, de tal forma que, quando alcançou a cátedra nas Arcadas, em 1960, com a tese sobre a Decadência, logo depois me convidou para ser assistente na mencionada disciplina.

Assim, em 1963, como homenagem ao sábio cicerone nos dificeis caminhos do Largo de São Francisco, tomei para tema de minha Livre-Docência os mesmos Princípios Gerais de Direito, os quais dediquei expressamente ao querido mestre e amigo.

Dois anos depois ele se aposentava pela compulsória, ocasião em que, por ato do Magnífico Reitor, fui nomeado catedrático-substituto, em sua honrosa sucessão na curul da Egrégia Congregação, de onde fui deslocado após três anos, para só retornar passadas outras duas décadas.

Entretanto, a aposentadoria de Nicolau Nazo não o afastou do magistério, que continuou exercendo na Universidade Católica nem da advocacia, já como consultor jurídico dos mais eruditos, já como militante do fórum onde tinha por lema irretorquível uma frase que sempre lhe ouvi de viva voz: "Advogar é provar"

Estas breves pinceladas são apenas a visão impressionista do esplêndido clarão dessa figura humana que orna o Panteão das nossas Arcadas, em meio a cujos Maiores emerge em posição exponencial.

E ao me permitir, reverente e contrito, aquinhoar a luciluzência desta incomparável galáxia do saber jurídico, peço vênia para ponderar que, entre os muitos caracteres que a engrandecem, há aqueles que, como Soares de Melo, se celebrizaram pela palavra, outros, como João Mendes Júnior, pela obra; outros ainda, como Spencer Vampré, pelo fascínio que exercia sobre os discípulos.

E averiguo com filial alegria que Nicolau Nazo se encastoa com facilidade em qualquer dessas constelações.

Pela palavra, suave-firme e carinhosa foi o guia dedicado, cioso de seus discípulos.

Pelas múltiplas facetas do seu saber jurídico, legou obras que são marcas na história das disciplinas de que tratou e em que foi concursado com grande distinção.

Finalmente, pela bondade, pela paciência e pelo exemplo, foi como um ser transfigurado, com a aura esplêndida do carisma verdadeiramente cármico das pessoas vocacionadas, que por este mundo passaram, como que na última fase da metamorfose do Homem para o Santo. 
Guia, sábio, nume, que das celestiais paragens onde certamente habità, com a sua ternura, com a sua presença, com as suas luzes, continue velando por nós e por nossa Faculdade velha e sempre nova, para que ao longo do ímpar destino histórico, na respeitável vetustez - continue cada vez mais sábia; e, na perene juventude, cada vez deslumbrante em seus vanguardeiros ideais. 